Publisher homepage: www.universepg.com, ISSN: 2707-4641 (Online) \& 2707-4633 (Print)

https://doi.org/10.34104/ijma.020.022030

International Journal of Management and Accounting

Journal homepage: www.universepg.com/journal/ijma

\title{
Impact of Green Human Resource Management (GHRM) practices in Garment industry: Bangladesh Perspective
}

\author{
Sajun Saha ${ }^{1}$, Rimon Sarker ${ }^{1}$, and Syed Meherab Ahmed ${ }^{1}$ * \\ ${ }^{1}$ Department of Human Resource Management, Jatiya Kabi Kazi Nazrul Islam University (JKKNIU), Trishal, Mymensingh, \\ Bangladesh \\ *Correspondence: mehrab375@gmail.com (Syed Meherab Ahmed, Dept. of Human Resource Management, JKKNIU, \\ Bangladesh)
}

\begin{abstract}
Green HRM means ecofriendly and sustainable development practice should be followed in every sector of HRM. It refers to polices, practices and system that influence employees of the organization green and sustainable implementation of resources for the betterment of the individual, society, natural environment and the business. The purpose of this Article is to indicate the best practices can be occurred by the help of green practices with HRM. How we are benefited by the help of green human resource management policies and practices. Green HRM also shifted the conventional policies and practices and giving some statement towards GHRM. Most developed countries like USA, china and UK are rapidly developed Green HR policies and practices. The developing countries are following. Now a day's most attention in Garments sector is drawn towards sustainable development. Garments industries have huge growth opportunities by going green practices and creating a new friendly environment that helps them reduce operational cost with carbon footprint. So far very little research has been conducted on this topic even in the advanced countries. Green management in 1997 prepared by McDonagh but there is no clear explanation which time GHRM actually invented. The strategy involves implementing various HR function such as recruitment, induction, training, and development, conducting performance evaluation, and determining the compensation of employees.
\end{abstract}

Keywords: GHRM, Garments industry, HR policies and practices, HR function, and Sustainable development.

\section{INTRODUCTION:}

The term "green human resource management" is the most commonly known and popular things now a days. Green is all about HRM related Practices required to achieve environmental objectives of Companies is to commit about sustainable development (Apriyanti, 2020). CSR is the main factor for introducing the green human resource management. Particularly environmental management has now become a global social norm. As the largest developing sector in Bangladesh is Garments industry and those sector is currently a major environmental polluter. The GHRM helps to prevent that type of

UniversePG I www.universepg.com problem. Through Human Resource Management conduct the environmental management is called green Human Resource Management (Gazi, 2020).

The concept of GHRM originated from the impetus for organizations to integrate sustainability into their internal activities and decision making. The concept of sustainable development first entered common usage when outlined in the United Nations Brundtland Report that defined it as "development that meets the needs of the present without compromising the ability of future generations to meet their own needs" sustainable development differs from traditional approaches to growth by simultaneously integrating 
considerations of economic development, social inclusion, and environmental protection.

\section{REVIEW OF LITERATURE:}

The GHRM theories is one of the most commonly used conceptualizations of the impact of human resource management practices on organizational performance in empirical studies. Wehrmeyer (1996), discuss in his book about connection between environmental management and human resource management. We found that how effect environmental issue to influence the working environment and flourishing the mind of an employee and increase productivity. Renwick et al. (2008) and MullerCarmen et al. (2010), Company's environmental management is a main focus part of their articles. They provide how practice green human resource management in the recruitment, selection, training and development performance management and evaluation, rewards and recognition etc. sector separately in the HRM process of the organization (Milon, 2019).

Jabbour (2013), in his article he discussed about environmental protection and how prevent pollution by taking some steps in the working sector. Implementation of some policies human resource management which he formulate to protect the environment from pollution and waste of environmental welfare resource. Renwick et al. (2013), the contribution of trade union of an organization is to be cleared by this article. Green practice mostly depends on the commitment of a worker. When a worker cannot satisfy with their work then their actual output could not be achieved (Alam, 2020). The correlation between top level and trade union and how they help each other to established green human resource management in the organization. Opatha and Arulrajah (2014), Corporate environmental culture of their article main topic and they provided some statement about green employee. How employee to be green what work can be employee green. In this article they showed that enhance and retain green sagacity among the employee so that the employee can fully concentrate on the green HRM rules.

Ahmad (2015), in his article we find some essential issue related to the GHRM which not only influencing awareness toward environmental affairs but also helping to establish social and economic wellbeing of both the organization and employees. Parida et al. (2015), the actual destination of green human resource management is sustainable development through human resource management. Increased the boundaries of the traditional human resource management practice and policies towards more sustainable and environmental strategies. Mousumi \& Nilanjan (2015), This article focus on fourth international conference on international business, monetary system, economics and social sciences how those factors influences organizational sustainability and how GHRM is an influential factor to protect and develop the GHRM practice in the organization. Ren et al. (2018), publications was published several research paper which is helpful for every researcher. In his research he discusses the matter of external pressures to follow GHRM and internal perspectives which can develop GHRM.

Koberg and Longoni (2019), Green HRM practice mostly depends on the basis of organizational structure. Some basic factors of organization help for sustainable outcomes by reducing the environmental effects. Those factors were pointed in this article and how it influences the sustainable development. Yusliza et al. (2019), Their article review all the GHRM related research paper and they provide some issue which classified the actual practice of GHRM on the basis of organizational level. Top mid and lower level and which practices for each level are to mention by this article. Shah (2019), green health and safety of employee how increase the performance of an employee discuss in this article. The eco-friendly working environment helps to increase the performance of an employee and this green environment keep the employee healthy in this way their future would be more secured (Shuvro et al., 2020).

\section{Objectives of the Study:}

The primary objectives of this study are to show level of Green HRM practice in the different Garments industries in Bangladesh. The following specific objectives are pointed out to achieve the main objective:

1. Identify When GHRM start in the Garments sector in Bangladesh. 
2. Compare the worker satisfaction level among different Garments industries.

3. Identify the Gap among garments on the basis of labor turnover and yearly profit turnover who properly follow GHRM and who don't.

\section{METHODOLOGY:}

Data Collection, Technique and Questionnaire Design - Through questionnaire survey the primary data was collected from the respondents. Three major parts included in the questionnaire: first - demographic information of the respondents', second - the statements relating to the perception about job satisfaction and third - the statements relating to the perception about how the respondents' degree of emphasis on the job satisfaction. Two-Point Likerttype scale, where $1=$ average, $2=$ satisfied, 120 questionnaires were distributed to obtain desired level of information from four selected Garments. Among them, 100 usable responses were found. Secondary data are collected from the twenty selected garments industry among different demographic location.

Pre-test and Pilot Testing - Whether to see the changes are necessary or not before going for the actual survey, the researchers pre-tested the questionnaire. Some people are selected as initial respondents in the pre-testing (pilot survey) session. In the pilot survey it is found some important correction areas of the questionnaire such as interpretation of the key and technical concepts, and some possible areas of confusion or ambiguity. The questionnaire was modified based on pre-test suggestions.

Locating Respondents and Sample Size - The survey of the study was carried out in Dhaka, Gazipur, Narayangonj and Mymensingh district including the different districts of Bangladesh using questionnaire. A random sampling method had been adopted for choosing the respondents from different garments. 120 questionnaires were sent to the respondents; among them 100 usable responses were received.

Data Analysis and Tools Applied - To arrive at the intended analysis, the participants' responses were put into SPSS, MS Excel 2007 software and several statistical analyses were performed to analyze and interpret the data. Descriptive statistics was used to show the perception of the respondent. (Amount of worker who leave $\div$ Total amount of worker $) \times 100=$ labor turnover rate.

\section{Why GHRM is Essential of Garments Industry?}

The increasing rate of carbon causes by the industry revolution in the earth. So; our responsibilities were to protect the universe. We are very careful about the people who related to the industry they have minimize their environmental exaggerated activities and GHRM restrict those activities for betterment organizational culture and structure. Which people only concern for earning profit they are liable.

Beneficial for Environment - The role of Green HRM is to protecting the environment, therefore, it is recommended to take the necessary steps for establishing green HRM. Green HR plays some roles in the garment industry to protect the environment those are following:

1. To avoid or reduce global warming.

2. To avoid or reduce natural disasters.

3. To avoid or reduce the cause of health diseases Pollution.

4. To ensure balance in life relationships and the environment.

5. To ensure the survival people and businesses Organization

6. To ensure dust free environment.

7. Develop or enhance waste management system to reduce atmospheric (air, water, soil) pollution.

8. Use more energy efficient equipment to reduce energy consumption as well as emission of greenhouse gases.

Beneficial for Human Resource - Elton Mayo's Hawthorne studies were focused on corporate strategy with emphasis on the socio psychological aspects of human behavior in organization and GHRM majorly influence that aspect which related to the human resource in Garments industry.

1. To increase efficiency of garments factory employee and worker.

2. Cost effective production

3. Better employee engagement and retention. 
4. Help organizations to reduce employee carbon footprints by electronic filing, car sharing,

5. Reduction of paper use by the help of teleconferencing and virtual interviews

6. By the help of Green human resource management in Garments industry they bring down costs without losing their talent.

7. GHRM helps to achieve higher job satisfaction and commitment which leads to higher productivity and sustainability.

Waste Reduction - Green human resource management influence waste reduction efficiently and helps to construct sustainable development framework.

- Reduce cost when cut cost in accordance with the function of GHRM.

- Reduce paper pen uses in any organizational work.

- Reduce business travel \& Focus on teleconferencing to minimize the emission of carbon-di-oxide.
- Reduce plastic water bottle

- Highly care about uses of water \& leakage of drainage system to ensure efficient use of water \& to reduce water pollution.

Recycle Garbage - Concentrate on recycling where possible, that will minimize the amount of wastage as well as pollution. Consider alternative energy sources which are more environment friendly such as- wind power, solar energy, etc. those resources will not be finished anymore so this energy use several times and those energy are eco-friendly. The recycle product reduces the garbage of our society and that reason soil water and weather get rid of a large number of rubbish and garbage wastage.

\section{Life Cycle of Green Practice with Human Capital -} Human capital is a production factor which an intangible asset, provided by human beings. Our creativity, idea, knowledge, skill, values and personality attributes all from part of the human capital that influence for the creation of goods and services.

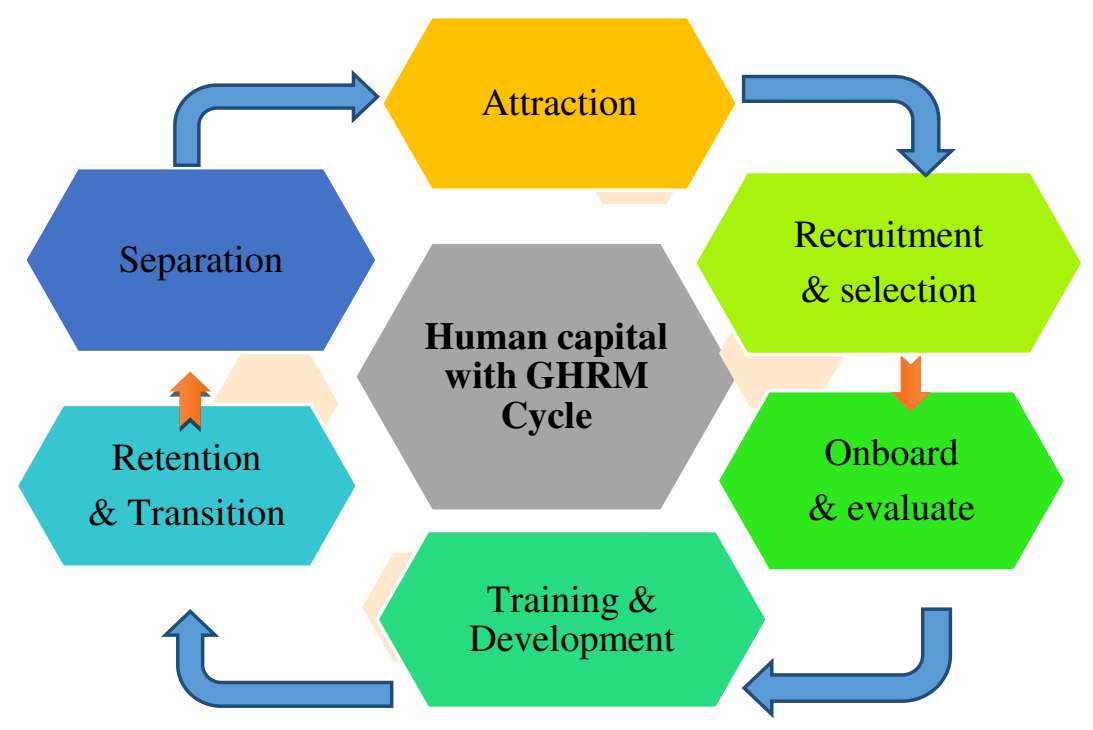

Fig 1: Lifecycle of human capital.

1) Attraction: GHRM helps to produce ecofriendly product for this reason employer and employee and job seeker attract to this types of job. Environmental management is possible by the helps of Green HRM so people are willing to contribute those types of job sector. Which garments company follow the strategy of green human resource management these companies job is more valuable and lucrative to the job seekers.

2) Recruitment and selection: In the recruitment process the offering should be inline rather than pestering hard copy spreading. Because poster and hard copy paper made from wood and wood are come from tree. Every year many 
trees cutting down for met the extra demand of paper.

There is some influential issue related to the selection process. The selection exam taken in computer and verbal rather than paper pen exam. Those types of people should be hired who take that job as his passion for Sustainable development.

3) On boarding \& Evaluation: It is the process of integrating a new employee into the organization and its culture. Tactics used in this process include formal meeting, lectures, videos, printed material, or computer based orientations to introduce human capital through implementing green HRM in the job. In the appraisal stage green HRM focus on some aria which related to the green human resource management. The standard should be fixed on the basis of social welfare. Evaluation process must be online and secondary data basis so time saving work should be possible and paper pen work should be avoided.

4) Training \& Development: For sustainable development training must be needed. Every employee should follow some environmental development issue. Green HRM helps to create a hygienic working environment so the employee much involve to their work. Their training process must be authentic for their favorable environment. In this way employee increase their efficiency in the green working environment for sustainable development.

5) Retention and transition: when eco-friendly working environment provide to the employee then they cannot leave the organization. In a garments industry when one experience worker leave the organization then the organization loose an assets. Which a garment properly follow the rules of green HRM this garments job is to be a lucrative job for every employee. Human capital transition to be skilled knowledge which is converted into many ways for any activities in a garments industry.

6) Separation: Sufficient Human capital is always should be needed in garments industry so they cannot leave a potential worker. For sustainable development loosing of potential human capital is not a good sign. Which people serve for their country they have a proper platform for serving through those garments who maintain and follow the framework of green HRM.

Analysis Part- At first we took some garments from the industry which follow green human resource management in their HRM process. Divided those garments in 4 types on the basis of garments companies which practice GHRM from 1year to above 10 years. We take 20 Garments where practices GHRM in their organizations from different times Table 1.

Table 1: Garments companies which practices GHRM from 1 year to above 10 years.

\begin{tabular}{|c|c|c|c|c|c|}
\hline No. & Name & $\begin{array}{l}1 \text { to } 3 \\
\text { years }\end{array}$ & $\begin{array}{l}3 \text { to } 5 \\
\text { years }\end{array}$ & $\begin{array}{l}5 \text { to } 10 \\
\text { years }\end{array}$ & Above 10 \\
\hline 1 & $\begin{array}{c}\text { Hamim group } \\
1984\end{array}$ & & & & $\checkmark$ \\
\hline 2 & $\begin{array}{c}\text { Ananta } \\
\text { Group } 1983\end{array}$ & & & & $\checkmark$ \\
\hline 3 & $\begin{array}{c}\text { Dbl group } \\
1991\end{array}$ & & $\checkmark$ & & \\
\hline 4 & $\begin{array}{c}\text { Pakiza group } \\
1982\end{array}$ & & $\checkmark$ & & \\
\hline 5 & $\begin{array}{c}\text { Standard } \\
\text { Group } 1984\end{array}$ & & & $\checkmark$ & \\
\hline 6 & $\begin{array}{c}\text { Fakir Group } \\
1988\end{array}$ & & & $\checkmark$ & \\
\hline 7 & $\begin{array}{c}\text { BITOPI } \\
\text { Group } 1984\end{array}$ & & $\checkmark$ & & \\
\hline 8 & $\begin{array}{c}\text { Epic group } \\
1971\end{array}$ & & & & $\checkmark$ \\
\hline 9 & $\begin{array}{l}\text { Mohammadi } \\
\text { group } 1986\end{array}$ & & $\checkmark$ & & \\
\hline 10 & $\begin{array}{l}\text { Opex Sinha } \\
\text { group }\end{array}$ & & & $\checkmark$ & \\
\hline 11 & $\begin{array}{c}\text { Givensee } \\
\text { Group of } \\
\text { Industries } \\
1982\end{array}$ & & $\checkmark$ & & \\
\hline 12 & $\begin{array}{c}\text { ZEX Fashion } \\
\text { Bangladesh } \\
2013\end{array}$ & $\checkmark$ & & & \\
\hline 13 & $\begin{array}{c}\text { Epyllion } \\
\text { Group } 1994\end{array}$ & & $\checkmark$ & & \\
\hline 14 & $\begin{array}{c}\text { KDS group } \\
1983\end{array}$ & & & $\checkmark$ & \\
\hline 15 & $\begin{array}{c}\text { SQUARE } \\
\text { Textile } 1997\end{array}$ & & & $\checkmark$ & \\
\hline 16 & $\begin{array}{c}\text { Snowtex } \\
\text { group } 2014\end{array}$ & $\checkmark$ & & & \\
\hline 17 & $\begin{array}{c}\text { Beximco } \\
\text { fashions } 1997\end{array}$ & & & $\checkmark$ & \\
\hline
\end{tabular}




\begin{tabular}{|c|c|c|c|c|c|}
\hline $\mathbf{1 8}$ & $\begin{array}{c}\text { AJ Group } \\
1997\end{array}$ & & $\checkmark$ & & \\
\hline $\mathbf{1 9}$ & $\begin{array}{c}\text { Tusuka } \\
\text { Group 1997 }\end{array}$ & & $\checkmark$ & & \\
\hline $\mathbf{2 0}$ & $\begin{array}{c}\text { Akij textile } \\
\text { mills 1998 }\end{array}$ & & & & $\checkmark$ \\
\hline
\end{tabular}

Some garments start their operation very late but they follow green HRM above 10 years their situation better than which organization very early start their operation but green HRM practice from 3 or 5 years.

Green HRM practice in the HRM process:

Table 2: Which company practices green HRM in how many stages?

\begin{tabular}{|c|c|c|c|c|c|c|c|}
\hline No. & Attraction & $\begin{array}{c}\text { Recruitment \& } \\
\text { selection }\end{array}$ & $\begin{array}{c}\text { Onboarding \& } \\
\text { Evaluation }\end{array}$ & $\begin{array}{c}\text { Training \& } \\
\text { Development }\end{array}$ & $\begin{array}{c}\text { Retention \& } \\
\text { transition }\end{array}$ & Separation & $\%$ \\
\hline 1 & $\checkmark$ & $\checkmark$ & $\checkmark$ & $\checkmark$ & $\checkmark$ & $\checkmark$ & $100 \%$ \\
\hline 2 & $\checkmark$ & $\checkmark$ & $\checkmark$ & $\checkmark$ & $\checkmark$ & $\checkmark$ & $100 \%$ \\
\hline 3 & $\checkmark$ & $\checkmark$ & & & $\checkmark$ & & $50 \%$ \\
\hline 4 & & $\checkmark$ & $\checkmark$ & & $\checkmark$ & & $50 \%$ \\
\hline 5 & $\checkmark$ & $\checkmark$ & $\checkmark$ & $\checkmark$ & $\checkmark$ & & $83 \%$ \\
\hline 6 & & $\checkmark$ & $\checkmark$ & $\checkmark$ & & & $50 \%$ \\
\hline 7 & & $\checkmark$ & & $\checkmark$ & $\checkmark$ & & $50 \%$ \\
\hline 8 & $\checkmark$ & $\checkmark$ & $\checkmark$ & $\checkmark$ & $\checkmark$ & $\checkmark$ & $100 \%$ \\
\hline 9 & & $\checkmark$ & $\checkmark$ & & & & $33 \%$ \\
\hline 10 & & $\checkmark$ & & & & & $17 \%$ \\
\hline 11 & & $\checkmark$ & & & $\checkmark$ & & $33 \%$ \\
\hline 12 & & $\checkmark$ & & & & & $17 \%$ \\
\hline 13 & & $\checkmark$ & & & $\checkmark$ & & $33 \%$ \\
\hline 14 & & $\checkmark$ & $\checkmark$ & & $\checkmark$ & & $50 \%$ \\
\hline 15 & $\checkmark$ & $\checkmark$ & $\checkmark$ & $\checkmark$ & $\checkmark$ & & $84 \%$ \\
\hline 16 & & $\checkmark$ & & & & & $17 \%$ \\
\hline 17 & $\checkmark$ & $\checkmark$ & $\checkmark$ & $\checkmark$ & $\checkmark$ & $\checkmark$ & $100 \%$ \\
\hline 18 & & $\checkmark$ & $\checkmark$ & & $\checkmark$ & & $50 \%$ \\
\hline 19 & & $\checkmark$ & $\checkmark$ & & & & $33 \%$ \\
\hline 20 & $\checkmark$ & $\checkmark$ & $\checkmark$ & $\checkmark$ & $\checkmark$ & $\checkmark$ & $100 \%$ \\
\hline
\end{tabular}

After taking 20 garments companies we just found out the green practice in HRM sector. We broke the HRM process in six stages and found which company practices green HRM in how many stages. On the basis of Green practices we valued in percentage and which company follow green HRM in their all HRM process they given 100 out of 100 that means $100 \%$ and which garments practices green HRM in some stages they give value according to the percentage. Those garments position is better which percent is close to 100 .

Practices of GHRM - In attraction stage out of 20 garments 7 garments follow green HRM and recruitment \& selection stage 20 out of 20 so we can say that every organization in Bangladesh follow green practices in this stage because the recruitment and selection were online basis on paper pen use for this. In separation stage only a few garments follow the green human resource management process. $25 \%$ follow green practice in the last stage of HRM process. Total $56.7 \%$ follow the GHRM in the Bangladesh garments industry.

\section{When they start GHRM in their sector:}

Yearly basis four types of classification given below and take one garments from one type. Which company starts green practice from 1 to 3 year in this area we select Snowtex group and 3 to 5 years we took AJ group and among 5 to 10 years garments we took Fokir group and above 10 years Hamim group randomly selected and we took 25 workers for responder from every selected garments. We checked 
the satisfaction level among those garments' workers. We found the percentage value of satisfactory level among the worker and we must say that which garments formulating their frame work early on the basis of GHRM their worker more satisfied from late started. Selected one garment from every yearly basis group \& find satisfaction level of workers Table 4.

Table 3: Percent level who follow GHRM in the particular process of HRM.

\begin{tabular}{|c|c|c|c|c|c|c|c|}
\hline Name & Attraction & $\begin{array}{c}\text { Recruitment } \\
\text { \& selection }\end{array}$ & $\begin{array}{c}\text { On boarding \& } \\
\text { Evaluation }\end{array}$ & $\begin{array}{c}\text { Training \& } \\
\text { Development }\end{array}$ & $\begin{array}{c}\text { Retention \& } \\
\text { transition }\end{array}$ & Separation & Total \\
\hline Out of & 20 & 20 & 20 & 20 & 20 & 20 & 120 \\
\hline Total & 7 & 20 & 13 & 9 & 14 & 5 & 68 \\
\hline$(\%)$ & $35 \%$ & $100 \%$ & $65 \%$ & $45 \%$ & $70 \%$ & $25 \%$ & $56.7 \%$ \\
\hline
\end{tabular}

Table 4: Percentage of satisfaction level of workers.

\begin{tabular}{|c|c|c|c|c|c|c|c|}
\hline \multicolumn{2}{|c|}{ When they start from } & \multicolumn{4}{|c|}{ Worker satisfaction } \\
\hline Years & Total & $(\%)$ & $\begin{array}{c}\text { Randomly selected } \\
\text { company name }\end{array}$ & & \multicolumn{3}{|c|}{ Satisfaction level } \\
\cline { 5 - 8 } & & & & Total & average & satisfied & $(\%)$ in good \\
\hline $\mathbf{1}$ to 3 years & 2 & $10 \%$ & Snowtex group & 25 & 17 & 8 & $32 \%$ \\
\hline $\mathbf{3}$ to 5 years & 8 & $40 \%$ & AJ group & 25 & 14 & 11 & $44 \%$ \\
\hline $\mathbf{5}$ to 10 years & 6 & $30 \%$ & Fokir group & 25 & 09 & 16 & $64 \%$ \\
\hline Above 10 & 4 & $20 \%$ & Hamim group & 25 & 2 & 23 & $92 \%$ \\
\hline Total = & 20 & $100 \%$ & & $=100$ & & & $58 \%$ \\
\hline
\end{tabular}

Table 5: Yearly Turnover \& Labor Turnover.

\begin{tabular}{|c|c|c|c|}
\hline $\begin{array}{c}\text { Garments } \\
\text { name }\end{array}$ & $\begin{array}{c}\text { Green } \\
\text { HRM } \\
\text { practice }\end{array}$ & $\begin{array}{c}\text { Yearly } \\
\text { turnover US } \\
\text { (\$) }\end{array}$ & $\begin{array}{c}\text { Labor } \\
\text { turnover } \\
\text { rate }\end{array}$ \\
\hline $\begin{array}{c}\text { Hamim } \\
\text { group }\end{array}$ & $100 \%$ & 550 million & $0.021 \%$ \\
\hline $\begin{array}{c}\text { Fokir } \\
\text { group }\end{array}$ & $50 \%$ & 295 million & $0.038 \%$ \\
\hline AJ group & $50 \%$ & 267 million & $0.040 \%$ \\
\hline $\begin{array}{c}\text { Snowtex } \\
\text { group }\end{array}$ & $17 \%$ & 250 million & $0.076 \%$ \\
\hline
\end{tabular}

Hamim group fully follow Green HRM in their HRM process and we found that their yearly turnover 550 million US dollar which is height profit earner in the garments industry. We also see that the labor turnover rate is $0.021 \%$ where green practice rate is $100 \%$ and where green practice below $50 \%$ there labor turnover rate is high. How many workers exist in the beginning in the work add to the new appointing workers during the year and deduct the amount of worker company fired and also deduct how many worker die during the year those the amount of worker leave the organization. (Amount of worker who leave $\div$ Total amount of worker) $\times 100=$ labor turnover rate.

Analysis Gap - In this article we found some analysis gap which helped to understand the actual gap of this sector and for what reason our need to be following GHRM those are revealed in this article.

1. Some companies start their operation very early but they follow CSR and GHRM in a recent period this company position is average.

2. Which garments start their operation very recent but they follow Green HRM practices their position better. 
3. We classified the HRM practice in six parts and we found that every garments follow green practices in recruitment and selection process but attraction and separation period some garments follow GHRM and their position better than other garments.

4. In the garments sector do not properly follow the Green practices in their HRM sector. Now a day Garments' $56.7 \%$ follow GHRM in their HRM sector.

5. We found that the worker satisfaction level of some garments company and which company follows properly green HRM their worker satisfaction level high.

6. Yearly turnover differ from one another on the basis of the practice of GHRM. Which company's practice more Greene their labor turnover rate low and yearly profit turnover is high.

Barriers - There have some obligation to establish and maintain green human resource management in the garments industry. Those barrier are given below -

1) Green human resource management is not familiar for our country so the implementing cost high.

2) As an over populated country Bangladesh has not proper support for following the green HRM.

3) Lack of skilled human resource we cannot organize the framework of a garments industry.

4) There is no alternative of GHRM either you follow it or not.

5) It is a rising concept so lack of information is common for Green HRM.

6) Bangladeshi people does not take any new concept in their working area as a result they avoided this type of environmental management activities.

7) There are some owners of garments industry think that they just earn profit without any concentration about our ecological system.

\section{RECOMANDATIONS:}

Bangladesh is an over populated country. Already it has 160 million people, in recent time Bangladesh is a country of immense potential because increasing population is an assets and no one understands this better than HRM. For labor turnover reduction we should follow the GHRM and the yearly profit turnover also influence by the helps of GHRM so doing garments company profitable we should follow the terms of GHRM.

Employee satisfaction is to depend on ecofriendly work environment. Therefore it is necessary to ensure the proper use of HRM with effective implications and that would be possible through the green HRM. Green HRM is one of the things that must be done rightly in the workplace for surviving at present situation. Environmental friendly HR activities should be followed in the Green HRM. In the other word Green HRM means ecofriendly and sustainable development practice should be followed in every implication sector of HRM.

\section{CONCLUSION:}

Generally Green HRM involves two essential elements Eco friendly HRM practice and conservation of knowledge capital. Green initiatives should be a part of corporate social responsibilities. Green HRM also shifted the conventional policies and practices and giving some statement towards GHRM. Most developed countries like USA, china and UK are rapidly developed Green HR policies and practices. The developing countries are following most attention in Garments sector is drawn towards sustainable development. Garments industries have huge growth opportunities by going green practices and creating a new friendly environment that helps them reduce operational cost with carbon footprint. Employee engagement has also been possible by the help of GHRM. The Green human resource management theories is one of the most commonly used conceptualizations of the impact of human resource management practices on organizational performance in empirical studies.

\section{ACKNOWLEDGEMENT:}

Thanks to all those persons, who have assisted us, providing us co-operation. The staffs and management of Garment industry was very co-operative and helpful.

\section{CONFLICTS OF INTEREST:}

The authors declare that they have no competing interests with respect to the research. 


\section{REFERENCES:}

1. Ahmad S. (2015). Green Human Resource Management: Policies and practices, Cogent Business \& Management, 2: 1030817. https://doi.org/10.1080/23311975.2015.1030817

2. Alam QN. (2020). Impacts of macroeconomic variables on the stock market returns of South Asian region, Can. J. Bus. Inf. Stud., 2(2), 2434. https://doi.org/10.34104/cjbis.020.24034

3. Apriyanti HW. (2020). Measurement and assessment of the developmental status of Islamic University governance: Indonesia perspective, Int. J. Manag. Account. 2(1), 1021. https://doi.org/10.34104/ijma.020.10021

4. Gazi MAI. (2020). Islamic perspective of leadership in management; foundation, traits and principles, Int. J. Manag. Account. 2(1), 1-9. https://doi.org/10.34104/ijma.020.0109

5. Jabbour C.J.C. (2013). "Environmental training in organizations: from a literature review to a framework for future research", Resources, Conservation and Recycling, 74, 144-155.

6. Koberg E. and Longoni, A. (2019). "A systematic review of sustainable supply chain management in global supply chains", Journal of Cleaner Production, 207, 1084-1098.

7. Milon M., (2019). Present scenario of human resource management (HRM) practices in the life insurance companies: Bangladesh perspective. Can. J. Bus. Inf. Stud., 1(6), 1727. https://doi.org/10.34104/cjbis.019.01727

8. Mousumi S. \& Nilanjan S. (2015). Green HRM: A Tool for Organizational Sustainability, Proceedings of the Fourth International Conference on Global Business, Economics, Finance and Social Sciences, Kolkata, Paper ID: K512

9. Muller-Carmem, (2010) M., Jackson, S., Jabbour, C.J.C. and Renwick, D. Green human resource managemente, Zeitschrift fur Personal forschung, 24(1), 95-96.

10. Opatha H. H., \& Arulrajah, A. A. (2014). Green Human Resource Management: Simplified general reflections. International Business Research, 7, 101-112. https://doi.org/10.5539/ibr.v7n8p101

11. Parida R, Raj S, Sharma P. \& Yadav V. (2015). Green HR: Analysis of sustainable practices incorporated by IT firms in India, Journal of Management Research, 1

12. Renwick D.W.S., Redman T., and Maguire S. (2013). "Green human resource management: a review and research agenda", International Journal of Management Reviews, 15(1), 1-14.

13. Ren S., Tang G. and Jackson S.E. (2018). "Green human resource management research in emergence: a review and future directions", Asia Pacific J. of Manag., 35(3), 769-803. https://doi.org/10.1007/s10490-017-9532-1

14. Shah M. (2019). "Green human resource management: development of a valid measurement scale", Business Strategy and the Environment, 28(5), 771-785.

15. Shuvro RA, Saha S, and Alam MJ. (2020). Measuring the level of job satisfaction of the employees of Grameen bank: an empirical study, Can. J. Bus. Inf. Stud., 2(1), 1-11. https://doi.org/10.34104/cjbis.020.01011

16. Wehrmeyer W., and Parker K.T. (1996). Identification and relevance of environmental corporate cultures as part of a coherent environmental policy, 163-185.

17. Yusliza M.Y., Norazmi N.A., Fawehinmi O. and Seles B.M.R.P. (2019). "Top management commitment, corporate social responsibility and green human resource management: a Malaysian study", Benchmarking: An International Journal, 26 (6), 2051-2078. http://doi.org/10.1108/BIJ-09-2018-0283

Citation: Saha S, Sarker R, and Ahmed SM. (2020). Impact of Green Human Resource Management (GHRM) practices in garment industry: Bangladesh perspective, Int. J. Manag. Account. 2(2), 22-30.

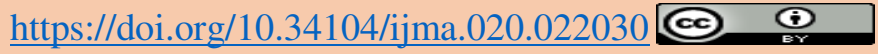

